\title{
Combined processing of Tricholoma equestre
}

\author{
EUGENIA SOBKOWSKA and WANDA WOŹNIAK
}

\begin{abstract}
SOBKOWSKA, E. \& WOZNIAK, W. 1978: Combined processing of Tricholoma equestre. - Karstenia 18 (suppl.).

The aim of this work was to elaborate an appropriate method of preserving mushrooms for further processing and to extend the list of mushroom products. A combined processing method is developed for Tricholoma equestre, a fungus which appeares in Polish forests in method is developed for Thicholoma equestre, a fungus which appeares in polish forests in autumn in large amounts. This method consists of freezing the mushrooms of edible quality
classified previously after preliminary treatment into two parts: one of high quality and equal quality and equal dimension for marketing as frozen mushroom, and the other for successive processing in the post seasonal time.

The yield and quality of the products obtained, as dependent on the quality of a raw material and mode of technological treatment, was investigated. Generally, in this process the yield of frozen mushrooms of Tricholoma equestre makes up about $60 \%$ of the raw material of edible quality, and the remaining $40 \%$ can be processed further into concentrates and pastes.
\end{abstract}

E. Sobkowska \& W. Woźniak, Institute of Food Technology, Agricultural Academy in Poznañ, w. Wo jska Polskiego 31, Poznañ, Poland.

\section{Introduction}

Tricholoma equestre (L. ex Fr.) Quel ( = T. flavovirens (Pers. ex Fr.) Lund), a fungus growing on sandy soil, appears in Polish forests in large amounts in autumn. This is an aromatic fungus very popular in Poland. Two limitations make the industrial processing of $T$. equestre rather difficult: fragile structure and sand contamination.

The common industrial practice is to process this mushroom into acid (mostly) or salted conserves and to preserve by brining the mushrooms unprocessed during the season. In this treatment, however, they lose much of their original quality and attractiveness. This is connected with losses of soluble and aromatic compounds as well as with interchanges of mineral constituente (Charlampowicz et al. 1973).

The study presented in this paper on the freezing of Tricholoma equestre was perfermed in order to elaborate an appropriate method of preserving mushrooms for further processing and to extend the list of mushroom products.

\section{Materials and methods}

Fruit-bodies of Tricholoma equestre (L. ex Fr.) Quél, Suilzus luteus (L. ex Fr.) S.F. Gray, and Xerocomus badius (Fr.) Kühn, were collected from pine woods in western Poland (Miedzychód region) in the autumns of 1970-1977 and were kindly supplied by the company "Las" in 25-40 kg sample lots each. According to Polish Norm No. $\frac{\mathrm{PN}-76}{\mathrm{R}-78505}$ the mushrooms were of the first quality class.
Dry weight (at $105^{\circ} \mathrm{C}$ ), soluble solids (by refractometer), titrable acidity and Kjeldahl $\mathrm{N}$ were measured in the usual manner, and the catalase activity according to the method of Bach \& Oparin (cit. Bielozierski 1954). For sensory evaluation the five -unit organoleptic method of Tilgner (1957) was used. The technological investigations were conducted on pilot-plant scale. Mechanical cleaning was performed manually, using a knife. For washing a vibrating washer or tanks were used. To drip off the water the mushrooms were kept on meshed wire for $1 / 2$ hour. Blanching, if done, was performed in water for 4 minutes at $95-98^{\circ} \mathrm{C}$ with or without addition of $2 \%$ of citric acid and/or $1 \%$ of salt. For freezing, three alternative air blast devices were used: cold room $3.5 \times 4.5 \times 2.5 \mathrm{~m}$ at $-20^{\circ} \mathrm{C}$ for $3.5-4.0 \mathrm{~h}$ in $3 \mathrm{~cm}$ layer; tunnel $3.2 \times 8.0 \times 2.5 \mathrm{~m}$ at $-35^{\circ} \mathrm{C}$ for $1.5 \mathrm{~h}$ in $3 \mathrm{~cm}$ layer; and fluidized-bed belt tunnel (FBB tunnel) ZFT I, of Polish construction, $4.4 \times 17.9 \times 2.5 \mathrm{~m}$, at $-35^{\circ}$ $C$ for 10.5 minutes for $T$. equestre and for 21 minutes for $X$. badius and $S$. Zuteus. The frozen mushrooms were packed in $1 / 2 \mathrm{~kg}$ plastic bags and stored at $-20^{\circ}$ and $-25^{\circ} \mathrm{C}$.

\section{Results and discussion}

T. equestre is a mushroom of fragile structure easily breaking during transport and technological treatment. Therefore, before processing the fruit-bodies were classified according to shape, (conical and horizontal) and dimension (1.5-4.5, 4.5-6.0 and over $6 \mathrm{~cm}$ in diameter). In Table 1 the contribution of the different 
Table 1. Contribution of different classes of mushrooms in the total crop of Tricholoma equestre.

\begin{tabular}{|c|c|c|c|c|c|c|}
\hline \multicolumn{2}{|c|}{ Date of harvest } & \multirow{2}{*}{$\begin{array}{c}\text { Shape } \\
\text { Conical/horizontal }\end{array}$} & \multirow{2}{*}{$\begin{array}{c}\begin{array}{c}\text { Dimension } \\
\emptyset \mathrm{cm}\end{array} \\
1.5-6.0\end{array}$} & \multirow{2}{*}{$\frac{\begin{array}{l}\text { Contri- } \\
\text { bution } \%\end{array}}{100}$} & \multirow{2}{*}{$\begin{array}{l}\begin{array}{l}\text { Broken after } \\
\text { washing } \%\end{array} \\
5.0\end{array}$} & \multirow{2}{*}{$\begin{array}{l}\begin{array}{l}\text { Second clas: } \\
\% \text { of total }\end{array} \\
5.0\end{array}$} \\
\hline 1972 & Sept. 20 & & & & & \\
\hline & Oct. 4 & Conical/horizontal & $1.5-6.0$ & 100 & 5.2 & 5.2 \\
\hline & Oct. 19 & Horizontal & $1.5-6.0$ & 100 & 15.0 & 15.0 \\
\hline & Oct. 27 & Horizontal & $1.5-6.0$ & 100 & 16.5 & 16.5 \\
\hline \multirow[t]{5}{*}{1976} & Oct. 13 & Conical & $1.5-4.5$ & 39 & 2.7 & \\
\hline & & Horizontal & $1.5-4.5$ & 29 & 5.0 & \\
\hline & & Conical/horizontal & $4.5-6.0$ & 5 & 5.0 & 37.7 \\
\hline & & Broken & & 25 & 25.0 & \\
\hline & & Wastes & & 2 & & \\
\hline \multirow[t]{11}{*}{1977} & oct. 2 & Conical & $1.5-6.0$ & 100 & 1.0 & 1.0 \\
\hline & Oct. 12 & Conical & $1.5-4.5$ & 26 & 3.1 & \\
\hline & & Horizontal & $1.5-4.5$ & 38 & 4.3 & 35.2 \\
\hline & & Conical/horizontal & $4.5-6.0$ & 10 & 4.8 & \\
\hline & & Broken & & 23 & 23.0 & \\
\hline & & Wastes & & 3 & & \\
\hline & Oct. 20 & Conical & $1.5-4.5$ & 26 & 3.1 & \\
\hline & & Horizontal & $1.5-4.5$ & 46 & 5.1 & 35.7 \\
\hline & & Conical/horizontal & $4.5-6.0$ & 4 & 4.0 & \\
\hline & & Broken & & 23 & 23.0 & \\
\hline & & Wastes & & 1 & & \\
\hline
\end{tabular}

classes of mushrooms in the successive lots delivered by the mushroom purchasing centre is shown. At the beginning of the season (end of september and beginning of october) the ratio of mushrooms conical in shape is greater and they also withstand the washing process better. The conical fruit-bodies undergo breaking during washing in 1 to $3 \%$, whereas the horizontal in about 5\% (crops of 1976 and 1977; in 1972 the mushrooms were not sorted before washing). In the total lot about $25 \%$ of the fruit-bodies were broken during transport. As a result, about 35 to $40 \%$ of the total edible crop has to be treated technologically as second class material.

In Table 2 is shown the resistance to washing in tank and vibrating washers of unclassified material (broken during transport are included) and in Table 3 the influence of the time of washing in vibrating washer. The tank method resulted in a lower amount of second class material, but the sand was not removed completely as was evidenced in the sensory evaluation of cooked or fried mushrooms. The use of brine for holding before washing eliminates this defect, but only the vibrating washer ensures effectiveness in the line process.

In Table 4 is demonstrated the absorption of water during washing in the vibrating washer. Young fruit-bodies, conical in shape, with compact tramma and small hymenophore absorb less water $(30 \%$ and $11 \%$ for $T$. equestre and $X$. badius, respectively) than older mushrooms ( $35 \%$ and $27 \%$, respectively). The about $30 \%$ capacity of water absorption by fruit-bodies is consistent with our observations over several years on the dry matter content of different lots of mush-
Table 2. Effect of shape and dimension on the resistance to transport and washing of Tricholoma equestre.

\begin{tabular}{|c|c|c|c|c|}
\hline Date & Shape & $\begin{array}{c}\text { Dimension } \\
\varnothing \mathrm{cm}\end{array}$ & $\begin{array}{l}\text { Broker } \\
\text { washir }\end{array}$ & $\begin{array}{l}n \text { after } \\
\text { ng o }\end{array}$ \\
\hline October 1970 & $\begin{array}{l}\text { Conical/ } \\
\text { horizontal }\end{array}$ & $1.5-6.0$ & 6.0 & tank \\
\hline October 1971 & Conical & $1.5-6.0$ & 1.9 & tank \\
\hline \multirow[t]{2}{*}{ October 1972} & $\begin{array}{l}\text { Conical/ } \\
\text { horizontal }\end{array}$ & $1.5-6.0$ & 5.1 & tank \\
\hline & Horizontal & $>6.0$ & 15.7 & tank \\
\hline \multirow[t]{4}{*}{ October 1976} & $\begin{array}{l}\text { Conical/ } \\
\text { horizontal }\end{array}$ & $1.5->6.0$ & 29.1 & $\begin{array}{l}\text { vibrating } \\
\text { washer }\end{array}$ \\
\hline & Conical & $1.5-6.0$ & 11.1 & -"- \\
\hline & Horizontal & $1.5-6.0$ & 39.6 & $-"-$ \\
\hline & $\begin{array}{l}\text { Conical/ } \\
\text { horizontal }\end{array}$ & $>6.0$ & 14.1 & -"- \\
\hline October 2,1977 & Conical & $1.5->6.0$ & 1.0 & tank \\
\hline October 9,1977 & $\begin{array}{l}\text { Conical/ } \\
\text { horizontal }\end{array}$ & $1.5->6.0$ & 10.0 & tank \\
\hline
\end{tabular}

rooms as dependent on climatic conditions before gathering. For $T$. equestre the dry matter content varied from 6 to $9 \%$, the high values being obtained after a period of dry weather.

Very few investigation on the preservation of mushrooms by freezing are found in the literature and they generally deal with cultivated Agaricus bisporus (Tressler \& Evers 1957, Bötticher 1950, Gromley 1972, cook \& Herriot 1973). In the freezing technology of vegetables the necessary step after washing is blanching, the most important effect of which is the inhibition of oxidative enzymes. 
Table 3. Effect of washing method on the amount of broken mushrooms of Tricholoma equestre.

\begin{tabular}{|c|c|c|c|c|c|c|c|c|}
\hline \multirow[b]{2}{*}{ No. } & \multicolumn{2}{|c|}{$\mathrm{Class}$} & \multicolumn{2}{|c|}{$\mathrm{H} \circ \mathrm{Id}$ ing } & \multicolumn{3}{|c|}{ Washing } & \multirow{2}{*}{$\begin{array}{l}\text { Broken } \\
\text { mushrooms \% }\end{array}$} \\
\hline & Shape & $\begin{array}{c}\text { Dimension } \\
\emptyset \mathrm{cm}\end{array}$ & Solution & $\begin{array}{l}\text { Time } \\
\text { min }\end{array}$ & Method & $\begin{array}{l}\text { Changes } \\
\text { of water }\end{array}$ & $\begin{array}{l}\text { Time } \\
\text { min }\end{array}$ & \\
\hline \multirow[t]{4}{*}{1} & \multirow[t]{4}{*}{ Conical/horizontal } & \multirow[t]{4}{*}{$1.5-6.0$} & \multirow[t]{4}{*}{ Water } & \multirow[t]{4}{*}{15} & \multirow{4}{*}{$\begin{array}{l}\text { Vibrating } \\
\text { washer }\end{array}$} & \multirow[t]{4}{*}{-} & 5 & 15.8 \\
\hline & & & & & & & 7 & 20.2 \\
\hline & & & & & & & 10 & 29.1 \\
\hline & & & & & & & 15 & 36.4 \\
\hline 2 & Conical & $1.5-6.0$ & Water & 15 & $\begin{array}{l}\text { Vibrating } \\
\text { washer }\end{array}$ & - & 10 & 11.1 \\
\hline 3 & Conical & $1.5-6.0$ & $\begin{array}{l}\text { Brine } \\
1 \% \mathrm{NaCl}\end{array}$ & 15 & Tank & 3 & 5 & 1.0 \\
\hline 4 & Horizontal & $1.5-6.0$ & $\begin{array}{l}\text { Brine } \\
1 \% \mathrm{NaCl}\end{array}$ & 15 & Tank & 3 & 5 & 10.0 \\
\hline
\end{tabular}

Table 4. Absorption of water during washing of

Tricholoma equestre and Xerocomus badius

\begin{tabular}{|llccc|}
\hline Sample & \multicolumn{1}{c}{ Shape } & $\begin{array}{c}\text { Dimension } \\
\varnothing \mathrm{cm}\end{array}$ & $\begin{array}{c}\text { Washing } \\
\text { time of } \\
1 \mathrm{~kg} \text { sec }\end{array}$ & $\begin{array}{c}\text { Absorption } \\
\text { of water }\end{array}$ \\
\hline T. equestre & Conical & $1.5-4.5$ & 30 \\
& Horizontal & $1.5-4.5$ & 70 on ave. & 33 \\
& Conical/horizontal & $4.5-6.0$ & & 33 \\
& Broken & & 33 \\
& Conical & $1.5-4.5$ & & 32 \\
& Horizontal & $1.5-4.5$ & 100 on ave. & 37 \\
& Conical/horizontal & $4.5-6.0$ & & 38 \\
& Broken & & & 35 \\
X. badius & I class & & 23 & 11 \\
& II class & & 22 & 27 \\
\hline
\end{tabular}

During blanching in water the mushrooms lost on the average about $1 \%$ of the soluble solids, i.e. about $1 / 4$ of the total content, and about $0.1 \%$ of the total nitrogen, i.e. about $1 / 3$ of the total content (Fig. 1). When blanching in citric acid solution the titrable acidity rose additionally to about twofold (e.g. from $0.07 \%$ to $0.16 \%$ in $T$. equestre).

Reduction of the catalase activity is the positive effect of blanching. Total inhibition was not attained, however (Fig.2). The enzyme was more resistant in $S$. Luteus than in $T$. equestre, and about $1 / 4$ of the criginal activity remained after blanching. During six months of cold storage the activity dropped progressively, but a significant decrease was also observed in unblanced samples.

The changes in chemical composition were reflected in the sensory evaluation (Fig. 3, Table 5). Most affected after blanching was the general appearance of the frozen products. Compared with unblanced samples the fungi changed colour and shrank in size. Water blanching, washing out the soluble solids and flavour constituents, caused the lowering of odour and flavour scores by, on the average, one unit on the five unit organoleptic scale, The texture gradually became tough. Blanching in acid caused addition-
FIG I THE INFIUENCE OF BLANCHING ON THE CHEMICAL COMPOSITION OF FROZEN MUSHROOMS

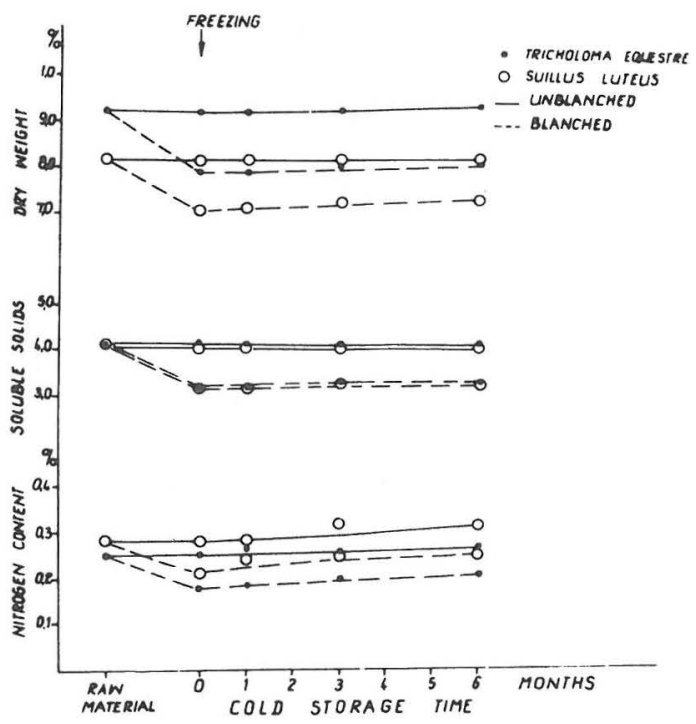

FIG.2. THE INFLUENCE OF BLANCHING ON THE CATALASE ACTIVITY IN FROLEN MUSNROONS

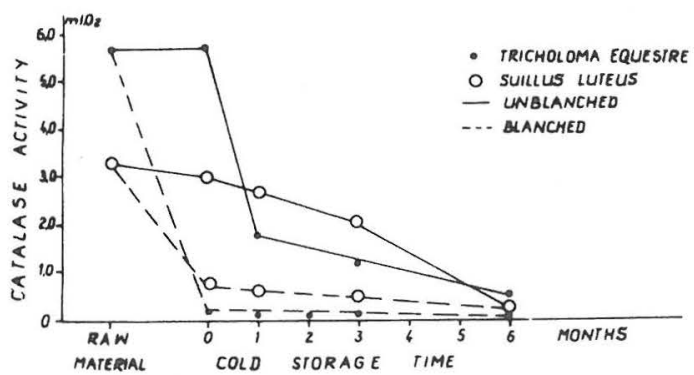


FIG 3. THE NFLUENCE OF MANCHING ON TME ORGAMOLERIC EVALUATION OF REOREN MUSMEOONS

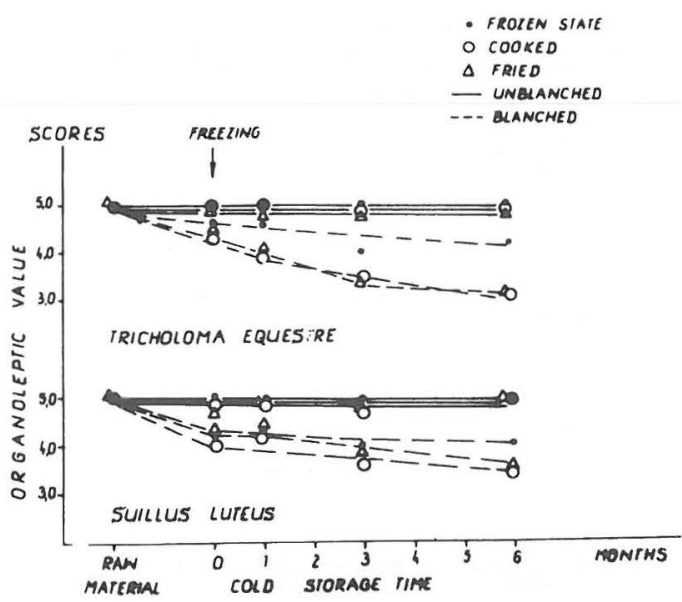

Table 5. Effect of packing of mushrooms before freezing on the quality of frozen Tricholoma equestre

\begin{tabular}{|c|c|c|c|c|}
\hline \multirow{3}{*}{ Characteristic } & \multicolumn{4}{|c|}{ Frozen } \\
\hline & \multicolumn{4}{|c|}{ Unblanched Blanced } \\
\hline & Loose & In bags & Loose & In bags \\
\hline \multicolumn{5}{|l|}{ Appearance } \\
\hline colour & 5.0 & 5.0 & 4.2 & 3.0 \\
\hline Mass homogenity & 5.0 & 3.0 & 5.0 & 2.5 \\
\hline \multicolumn{5}{|l|}{ Odour } \\
\hline Specificity & 5.0 & 4.5 & 4.5 & 3.1 \\
\hline Intensity & 5.0 & 5.0 & 4.0 & 4.0 \\
\hline Consistency & 5.0 & 5.0 & 5.0 & 5.0 \\
\hline General quality & 5.0 & 4.5 & 4.6 & 3.5 \\
\hline
\end{tabular}

ally an undesirable sour taste. During six months of cold storage these changes were intensified. Neither of them was found in unblanched samples after processing or after storage.

As shown in Table 5, the mushrooms frozen loose retained their original quality after the freezing process. In fungi packed in $1 / 2 \mathrm{~kg}$ plastic bags the mass homogeneity was the most impaired. Several conglomerates were found. After blanching the mushrooms frozen in bags formed a solid mass.

Unblanched, unpacked mushrooms were frozen in 20-35 kg lots in industrial freezers, i.e. in air blast cold room, belt tunnel, and fluidized-bed belt tunnel. No influence of the freezing methods has been observed on the chemical composition of either of the investigated varieties (Table 6). During storage the slight increase in the content of the estimated components was proportional in all cases to the water lost during 24 months of cold storage. The chemical composition of the investigated fungi was consistent with the results obtained by other Polish investigators (Charlampowicz \& Kutzner 1965, Karkocha 1961,Mlodecki \& Chmielnicka 1969). Neither were any clear differences observed in the organoleptic evaluation (Table 7), but the samples frozen in fluidized-bed belt tunnel obtained a slightly higher mean scores than those frozen in ordinary tunnel and cold room freezers. Some changes, however, have been observed after storing. Generally, during two years of cold storage a decrease of one unit of the five unit organoleptic scale occurred, which means a fall from very good to good quality. Cold storage temperature in the ranges of $-20 \pm 1^{\circ} \mathrm{C}$ to $-25 \pm 1^{\circ} \mathrm{C}$ did not influence the quality of the final product. After the third month of storage a difference of about 0.5 unit in the organoleptic values appeared between samples frozen by the different methods. The mushrooms frozen in fluidized-bed belt tunnel were of the highest quality, and those in the cold room freezer were of the lowest.

Table 6. Influence of freezing method on chemical composition of mushrooms during cold storage.

\begin{tabular}{|c|c|c|c|c|c|c|c|c|c|c|c|c|c|}
\hline \multirow{2}{*}{$\begin{array}{l}\text { Freezing } \\
\text { method }\end{array}$} & \multirow{2}{*}{$\begin{array}{l}\text { Storage } \\
\text { time } \\
\text { months }\end{array}$} & \multicolumn{3}{|c|}{ Dry weight \% } & \multicolumn{3}{|c|}{ Soluble solids \% } & \multicolumn{3}{|c|}{ Titrable acid \% } & \multicolumn{3}{|c|}{ Total N \% } \\
\hline & & $\begin{array}{c}T . \\
\text { equestre }\end{array}$ & $\begin{array}{c}S . \\
\text { Zuteus }\end{array}$ & $\frac{X .}{\text { badius }}$ & $\begin{array}{c}T . \\
\text { equestre }\end{array}$ & $\begin{array}{c}\text { S. } \\
\text { Zuteus }\end{array}$ & $\frac{X .}{\text { badius }}$ & $\begin{array}{c}T . \\
\text { equestre }\end{array}$ & $\begin{array}{c}\text { S. } \\
\text { Iuteus }\end{array}$ & $\frac{X .}{\text { badius }}$ & $\begin{array}{c}T . \\
\text { equestre }\end{array}$ & $\begin{array}{c}\text { S. } \\
\text { Iuteus }\end{array}$ & $\begin{array}{c}X . \\
\text { badius }\end{array}$ \\
\hline $\begin{array}{l}\text { Cold } \\
\text { room }\end{array}$ & $\begin{array}{r}0 \\
3 \\
6 \\
24\end{array}$ & $\begin{array}{l}7.4 \\
7.4 \\
7.5 \\
7.6\end{array}$ & $\begin{array}{l}7.2 \\
7.2 \\
7.3 \\
7.5\end{array}$ & $\begin{array}{l}8.9 \\
9.0 \\
9.0 \\
9.5\end{array}$ & $\begin{array}{l}3.1 \\
3.2 \\
3.2 \\
3.5\end{array}$ & $\begin{array}{l}3.9 \\
4.0 \\
4.0 \\
4.3\end{array}$ & $\begin{array}{l}5.1 \\
5.2 \\
5.3 \\
5.5\end{array}$ & $\begin{array}{l}0.07 \\
0.07 \\
0.07 \\
0.08\end{array}$ & $\begin{array}{l}0.15 \\
0.15 \\
0.15 \\
0.17\end{array}$ & $\begin{array}{l}0.10 \\
0.10 \\
0.11 \\
0.12\end{array}$ & $\begin{array}{l}0.216 \\
0.216 \\
0.218 \\
0.265\end{array}$ & $\begin{array}{l}0.273 \\
0.275 \\
0.280 \\
0.310\end{array}$ & $\begin{array}{l}0.336 \\
0.336 \\
0.330 \\
0.348\end{array}$ \\
\hline Tunnel & $\begin{array}{r}0 \\
3 \\
6 \\
24\end{array}$ & $\begin{array}{l}7.4 \\
7.5 \\
7.5 \\
7.6\end{array}$ & $\begin{array}{l}7.2 \\
7.3 \\
7.3 \\
7.5\end{array}$ & $\begin{array}{l}8.9 \\
9.1 \\
9.2 \\
9.4\end{array}$ & $\begin{array}{l}3.1 \\
3.3 \\
3.3 \\
3.6\end{array}$ & $\begin{array}{l}3.9 \\
4.0 \\
4.0 \\
4.2\end{array}$ & $\begin{array}{l}5.1 \\
5.2 \\
5.2 \\
5.4\end{array}$ & $\begin{array}{l}0.07 \\
0.07 \\
0.07 \\
0.08\end{array}$ & $\begin{array}{l}0.15 \\
0.15 \\
0.15 \\
0.16\end{array}$ & $\begin{array}{l}0.10 \\
0.10 \\
0.11 \\
0.12\end{array}$ & $\begin{array}{l}0.218 \\
0.220 \\
0.220 \\
0.260\end{array}$ & $\begin{array}{l}0.287 \\
0.298 \\
0.305 \\
0.320\end{array}$ & $\begin{array}{l}0.336 \\
0.344 \\
0.344 \\
0.356\end{array}$ \\
\hline FBB tunnel & $\begin{array}{r}0 \\
3 \\
6 \\
24\end{array}$ & $\begin{array}{l}7.4 \\
7.5 \\
7.5 \\
7.6\end{array}$ & 8.9 & $\begin{array}{l}8.9 \\
9.0 \\
9.0 \\
9.4\end{array}$ & $\begin{array}{l}3.1 \\
3.3 \\
3.3 \\
3.5\end{array}$ & & $\begin{array}{l}5.1 \\
5.2 \\
5.3 \\
5.4\end{array}$ & $\begin{array}{l}0.07 \\
0.07 \\
0.08 \\
0.08\end{array}$ & & $\begin{array}{l}0.10 \\
0.11 \\
0.12 \\
0.12\end{array}$ & $\begin{array}{l}0.220 \\
0.220 \\
0.231 \\
0.265\end{array}$ & & $\begin{array}{l}0.340 \\
0.344 \\
0.352 \\
0.351\end{array}$ \\
\hline
\end{tabular}


Table 7. Effect of freezing method and time of preservation on sensory value of Tricholoma equestre, Suilius luteus and Xerocomus badius.

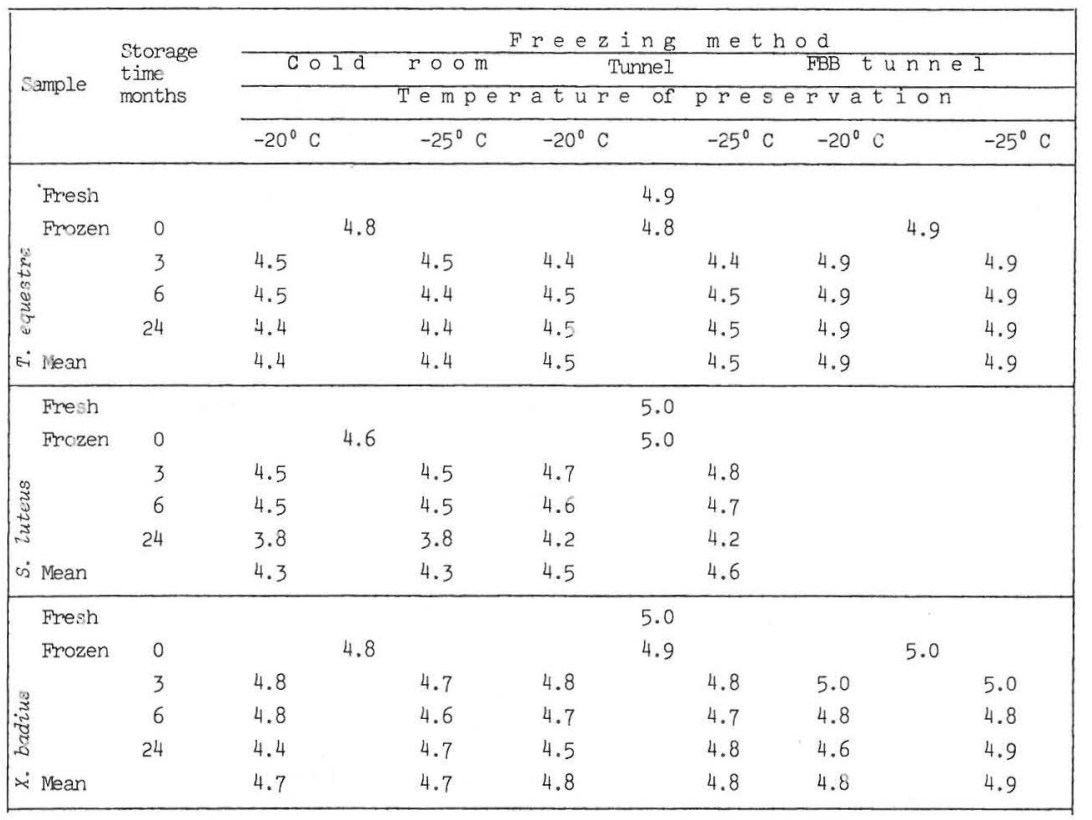

The organoleptic evaluation of frozen mushrooms after three and six months of storage was performed in winter and spring, respectively, when fresh fungi are not available. After 12 and 24 months of storage a direct comparison was possible. Reduction of the quality after 24 months of cold storage by only one unit, on the average, for all tested varieties, even those frozen by the simplest method in the air blast cold room, seems to indicate that this manner of preserving mushrooms is of high value.

As the result of this investigation, the combined processing method shown in Fig. 4 for T.equestre is proposed. This method consists of classifying of the mushrooms of edible quality after preliminary treatment (cleaning, washing and dripping of the water) into two parts: one consisting of the fruit -bodies that are unbroken and even in dimension (about . $60 \%$ of total) for marketing after freezing and storage in the frozen state, the other (about 40\%) for juice concentrates and mushroom and mushroom-vegetable paste production. These products can be obtained from second grade material directly or after freezing, in the latter case successively in the post-seasonal time.

\section{Acknowledgement}

The authors are indebted to Wojewodzkie Przedsiebiorstwo Przemyslu Chlodniczego (Cold Storage Plant) in Poznań for freezing and storing of the samples.

\section{References}

Bielozierski, A. \& Proskuriakow, N. 1954: Cwiczenia z biochemii roslin (Exercises in plant biochemistry). - p. 241, Warszawa, PWRiL.

Bötticher, W. 1950: Pilzverwertung und Pilzkonservierung. - $141 \mathrm{pp}$. München.

Charlampowicz, Z., Klawiter, M. \& Woß́niak, W. 1973: Znaczenie zawartości sodu i potasu w ocenie marynat grzybowych (The significance of $\mathrm{Na}$ and $\mathrm{K}$ contents in pickled mushroom evaluation). - Bromatologia i Chemia Toksykologiczna 4: 455460 .

Charlampowicz, Z. \& Kutzner, H. 1965: Characterystyka podstawowych skladników jadalnych grzybów krajowych (The chemical characteristics of Polish edible fungi). - Przemysl Spozywczy 19: 703-706. 
Cook, D.J. \& Herriot, V. 1973: Quality control: off -flavor in frozen vegetables. - Food Proc. Ind., Feb: $35-44$.

Gromley, T.R. 1972: Quality evaluation of frozen mushrooms. - Mushroom Sci. 8: 209.

Karkocha, I. 1961: Zarys chemii grzybow wyzszych (Chemistry of higher fungi). -Przemysl Spozywczy 15: $22-25$.

Mlodecki, H. \& Chmielnicka, J. 1969: Wklad nauki polskiej do poznania toksyczności i skladu chemicznego grzybów (The contribution of Polish science to knowledge on the toxicity and chemical composition of mushrooms). - Mykologia Stosowana 1: 7-12.

Tilgner, D.J. 1957: Analiza organoleptyczna zywności (Organoleptic analysis of food). - Warszawa, WPLis.

Tressler, D.K. \& Evers, C.F. 1957: The freezing preservation of food, Vol. 1. - Westport, The Avi Publ. Co.

Fig. 4. Technological process for Tricholoma equstre.

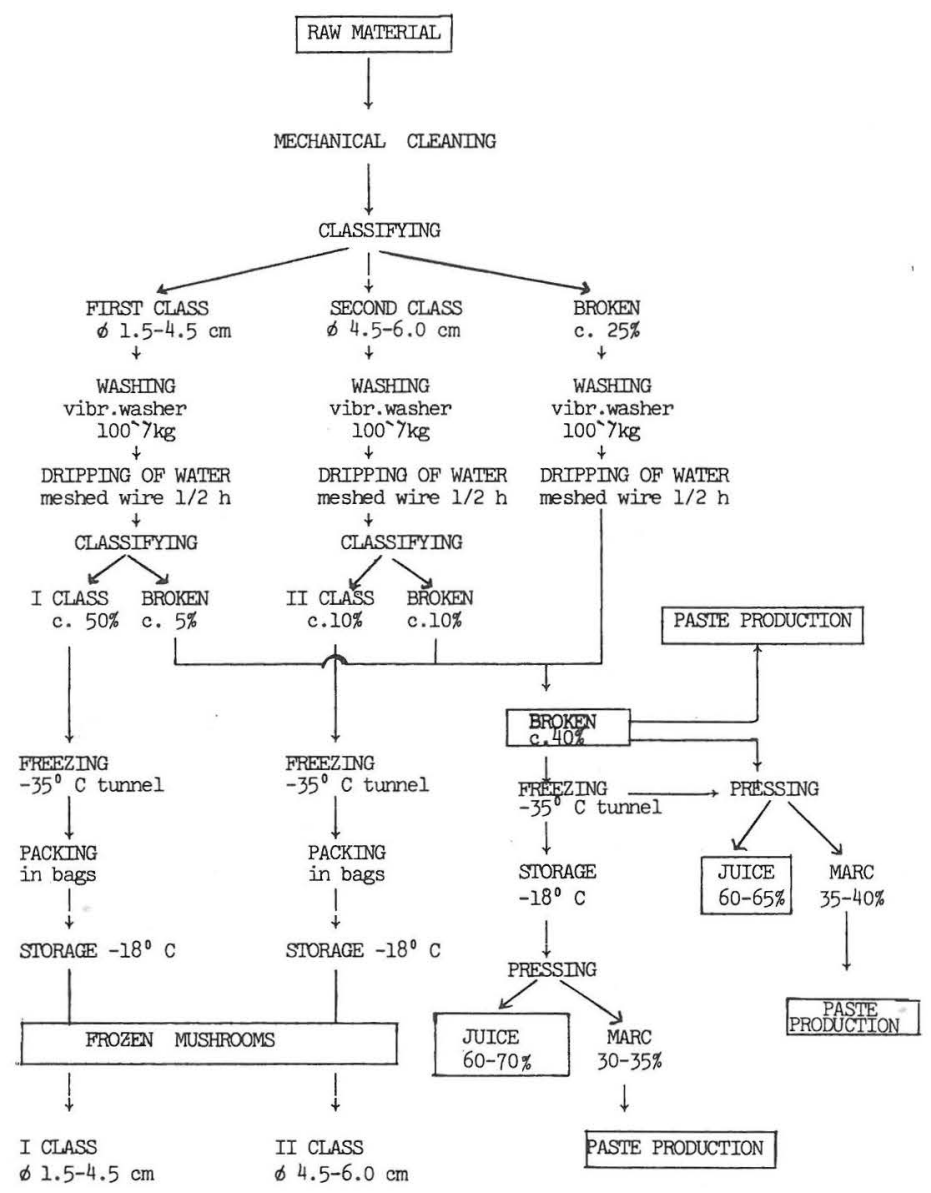

